\title{
Experimental investigation of Combustion, Performance and Emission in single cylinder diesel engine operated on blends of diesel and waste cooking oil
}

\author{
Ajay Kumar Yadav* and Anoop Kumar Pathariya \\ *Mechanical Engineering department, RGPV University,TIT college Bhopal, India \\ Received 22 May 2018, Accepted 25 July 2018, Available online 27 July 2018, Vol.8, No.4 (July/Aug 2018)
}

\begin{abstract}
We all are aware with the limited amount of energy and there resources. Today the agriculture sector needs good amount of energy, mainly energy from CI engine. As the consumption of energy increase the demand of energy also increases, mainly in petroleum sector. Today $90 \%$ of the total demand is full filled by the fossil fuels. The petroleum sector needs some alternative fuels to reach the demand. This research straightly focused on the use of waist cooking oil This concept also needs to aware with the consequences of reusing the WCO domestically and in restaurants. whenever the demand of energy needed we searches about alternative fuels so to complete the research for a alternative fuel we have to learn about fossil fuels, exhaust emissions, global warming etc. Here we used blends of waist cooking oil and diesel oil which are prepared by volume name as B5 using 5\% of WCO and B10 comprise 10\% WCO. The combustion, performance and emission properties are studied experimentally by combustion of different blends at different loads. It has to observed that in performance characteristic Mechanical efficiency is more for B10 when compare with B5 and conventional Diesel. When the load is increases fuel consumptions shows a considerable fall while it is noticeable that $\mathrm{CO}$ emission trend decreases and $\mathrm{NO}_{\mathrm{x}}$ increases after increasing some loads and $\mathrm{HC}$ are also indicate a down fall trend, on other hand $\mathrm{CO}_{2}$ emissions shows less affected.
\end{abstract}

Keywords: Combustion, Performance and Emission etc.

\section{Introduction}

Energy is a root of today's world which is available in different forms. Every country needs to use the different forms of energy in to its required form for the development and welfare of there mankind. The uses of energy spread its area in various sector like transportation, industries, agriculture and domestic sectors etc. Now a day, energy crisis is the prime issue for the world. Whole world expected that in this century the cost of crude oil or petroleum product will become coastally and also les available. The availability of major sources available in India like oil and cooking oil has increased from 0.25 million tons in 1947 to about 34.56 million ton in 1989-90.(S. Ram Kumar et al, 2016; K. Nantha Gopal et al, 2014)

According to latest reports India is become a second largest importer of cooking oil in the world. Waist cooking oil is considered as the potential oil which can be used after treatment with the diesel oil. There some qualities of WCO which strongly support the use of WCO with diesel fuel (S. Kathirvel et al

*Corresponding author's ORCID ID: 0000-0002-9561-0818 DOI: https://doi.org/10.14741/ijcet/v.8.4.19
2016). It should be noted that this also become a effective way to dispose the waist cooking oil by using it as a optional fuel in IC engines and helps to environments from the oil pollutiotn. As we all are well aware with the pollution due to the diesel hence many researchers are working with this problem to helps the environment (K. Muralidharan et al, 2011). There are many resources available to use directly with the diesel which are eco friendly and possess the properti0es near to the diesel fuel like Biomass, Biogas, LPG, CNG, vegetable oil and biodiesels (A. Abu-Jrai et al, 2011). The bio-fuels might be option for solution for worldwide crises of petroleum and also for energy conservation, efficiency and environmental protection (X.J. Man, C.S. Cheung et al,2016).

\section{Materials and methods}

\section{WCO production process}

The production of WCO in each country is on large scale and also vary depending on consumption and there need. In place of refine edible vegitable oil WCO is help to improve the economic feasibility of biodiesel. Before using of WCO, it should be properly treated to 
reduce the polluting discharge parameters or possibility of contaminations of water and land resources. Low price of feedstock and low cost of operations as compare to other alternative sources make it a strong selection. The production of biodiesel from the WCO can be substitute for the petroleum diesel. The cost of the waist cooking oil is cheaper than the other vegetable oil. WCO is catogorised based on its FFA. However the physical and chemical properties of waist coking oil are similar with virgin vegetable oil but the WCO have high cetane number, high flash point, high viscosity and specific heat.

It is found that the production of biodiesel from the waist cooking oil is quit challenging due to the presence of undesirable substances like fatty acids and water. Overall we can say that after some treatments and proper mixing WCO can be a promising alternative with diesel fuel in diesel engine some of the methods are here.

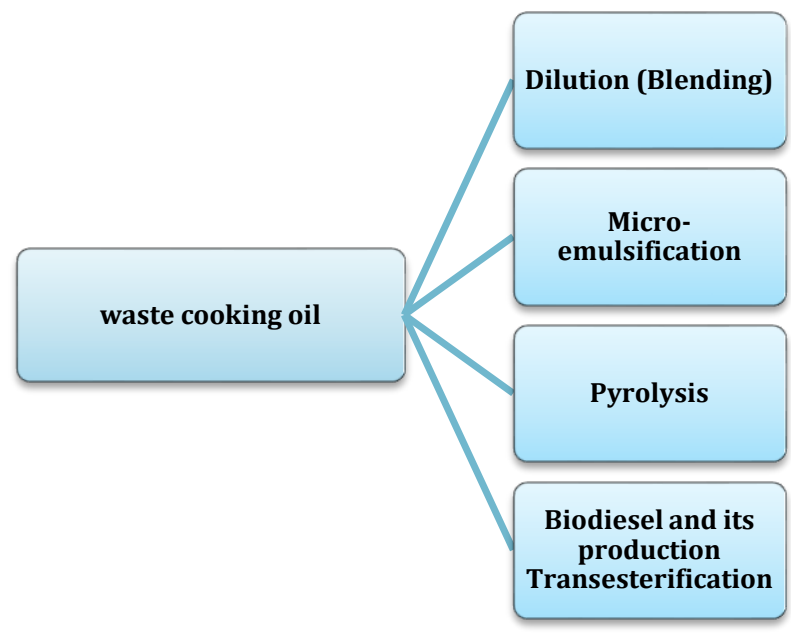

Methods for WCO as a fuel in IC engines

The preparation and analyses of testing fuel are carried out at ANACON lab Nagpur and the Department of Mechanical Engineering IC lab TIT college Bhopal. Total four samples were selected for testing which were (1) 100\%WCO,(2) 5\%WCO + 95\%Diesel, (3) 10\%WCO + 90\%Diesel and pure diesel. All blends were collected on the basis of volume and no presence of water molecules. ALL the samples are shown in figures. The equipments used for testing are listed below:

Table 3.1

\begin{tabular}{|c|c|c|c|}
\hline S.No & Property & Equipment & $\begin{array}{c}\text { Standard } \\
\text { method }\end{array}$ \\
\hline $\mathbf{1 .}$ & $\begin{array}{c}\text { Calorific } \\
\text { value }\end{array}$ & $\begin{array}{c}\text { Basic calorimeter } \\
\text { automatic }\end{array}$ & $\begin{array}{c}\text { IS 1350(part } \\
\text { 2) } 1970\end{array}$ \\
\hline $\mathbf{2 .}$ & $\begin{array}{c}\text { Cetane } \\
\text { number }\end{array}$ & $\begin{array}{c}\text { Aniline point } \\
\text { apparatus }\end{array}$ & ASTM D7170 \\
\hline $\mathbf{3 .}$ & $\begin{array}{c}\text { Flash \& fire } \\
\text { point }\end{array}$ & $\begin{array}{c}\text { Pensky- martens flash } \\
\text { \& fire point tester }\end{array}$ & ASTM D93 \\
\hline $\mathbf{4 .}$ & Viscosity & Viscometer & Karl fisher \\
\hline $\mathbf{5 .}$ & Moisture & Hot air oven & . \\
\hline
\end{tabular}

Measured Oil Properties of All Tested Oils

\begin{tabular}{|c|c|c|c|c|}
\hline$\sum_{\dot{s}}^{\dot{j}}$ & 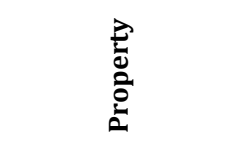 & ¿ & 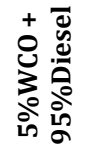 & 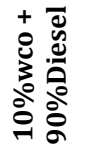 \\
\hline 1. & $\begin{array}{l}\text { Calorific Value } \\
\text { (Kcal/kg) }\end{array}$ & 8733 & 10205 & 9775 \\
\hline 2. & Density $\left(\mathrm{Gm} / \mathrm{cm}^{3}\right)$ & 0.912 & 0.765 & 0.850 \\
\hline 3. & $\begin{array}{c}\text { Viscosity at } 40^{\circ} \mathrm{C} \\
\text { (Cst) }\end{array}$ & 40 & 6.71 & 8.50 \\
\hline 4. & Flash point $\left({ }^{\circ} \mathrm{C}\right)$ & 265 & 85 & 74 \\
\hline 5. & Fire point $\left({ }^{\circ} \mathrm{C}\right)$ & 315 & 95 & 105 \\
\hline 6. & Cetane No. & 42.31 & 50.78 & 52.99 \\
\hline 7. & FFA as oleic acid & 0.40 & 0.40 & 0.40 \\
\hline 8. & Sp. Gravity & 0.912 & 0.85 & 0.89 \\
\hline 9. & Moisture $(\mathrm{Mg} / \mathrm{Kg})$ & ND & ND & ND \\
\hline
\end{tabular}

\section{Experimental setup}

The Experimental setup comprises a computerized single cylinder 4 stroke CI engine makes by Kirloskar and AVL digas 444 gas analyzer. The system stores the readings using high speed data skills system. Piezoelectric transducer, Eddy current dynamometer and engine software were provided by Apex innovations private ltd. Sangali india The systems store the reading using the high speed data skills system. Eddy current dynamometer, Piezo-electric transducer and engine software was provided by apex innovations Pvt. Ltd. Sangli, India. The test rig apparatus had a constant speed. The test rig apparatus consists of a constant speeding (1500RPM) 661cc, single cylinder, 4-stroke, Kirloskar make (model - TV1), and DI Diesel Engine attached to eddy-current type dynamometer. The eddy current dynamometer was used to apply load to the system. Load on the engine was changed by controlling the current given to the electromagnets. The calibrated Digital PT100 type temperature sensors were used for temperature measurement. The control panel has indicators for water temperature (inlet and outlet) for engine and the calorimeter, exhaust gas temperature to and from the calorimeter, rotameter for measurement of water flow to the engine and calorimeter, loading switch and the engine speed indicator. It is provided with necessary instruments for combustion pressure and crank-angle measurements. These signals are interfaced to computer through engine indicator P $\theta-\mathrm{PV}$ diagrams. A fuel tank was fabricated with appropriate valves for fuel supply. Fuel consumption was measured through graduated fuel metering tube controlled through the METERING / REGULAR option of the fuel metering cock. Air box with $U$ tube manometer measures air-flow rate and transmitters for air and fuel flow measurement process indicator and engine indicator. Rotameter are provided for cooling water and calorimeter water flow measurement. The software package used was complete in totally aspects for the above-referred calculations. 
Specifications of Computerized Diesel Test Engine Rig

Table -4.1

\begin{tabular}{|c|c|}
\hline Product & $\begin{array}{c}\text { Engine test setup single } \\
\text { cylinder 4- stroke diesel }\end{array}$ \\
\hline Make & Kirloskar \\
\hline Number of cylinder & Single \\
\hline Power & $5.2 \mathrm{KW}$ \\
\hline Cooling arrangement & Water cooled \\
\hline Speed & $1500 \mathrm{rpm}$ \\
\hline Compression ratio & $17.5: 1$ \\
\hline Cylinder Bore & $87.5 \mathrm{~mm}$ \\
\hline Stroke length & $110 \mathrm{~mm}$ \\
\hline Injection type & Direct injection \\
\hline Displacement volume & $661 \mathrm{cc}$ \\
\hline Swept volume & $661.45 \mathrm{cc}$ \\
\hline Dynamometer arm length & $185 \mathrm{~mm}$ \\
\hline Connecting rod length & $234 \mathrm{~mm}$ \\
\hline Stroke type & Four stroke \\
\hline Fuel injection starts before \\
TDC & $23^{\circ}$ \\
\hline
\end{tabular}

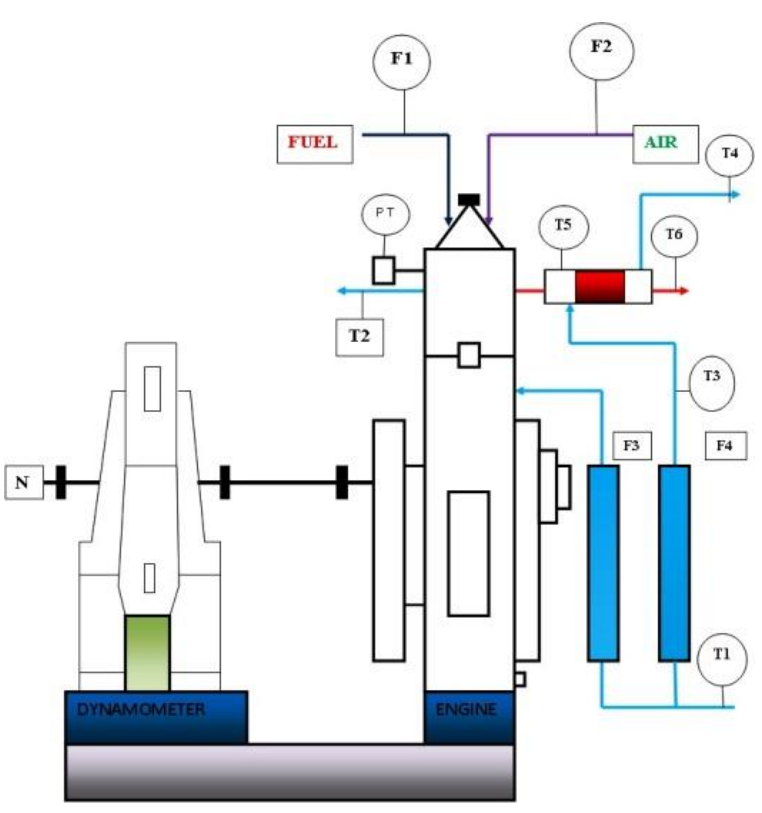

Fig 4.1 Line Sketch of Computerized Diesel Engine Test Rig Setup

\begin{tabular}{|c|c|c|c|c|c|}
\hline F1 & Fuel consumption $\mathrm{kg} / \mathrm{hr}$ & T1 & Jacket water inlet temp. $\left(\operatorname{deg} \mathrm{C}^{\circ}\right)$ & T5 & Exhaust gas to calorimeter inlet temp. \\
\hline $\mathbf{F 2}$ & Air consumption $\mathrm{kg} / \mathrm{hr}$ & $\mathbf{T 2}$ & Jacket water outlet temp. $\left(\operatorname{deg} \mathrm{C}^{\circ}\right)$ & $\mathbf{T 6}$ & $\begin{array}{c}\text { Exhaust gas from calorimeter outlet } \\
\text { temp. }\end{array}$ \\
\hline $\mathbf{F}$ & Engine water flow $(\mathrm{lph})$ & $\mathbf{T 3}$ & Calorimeter water inlet temperature & $\mathbf{P T}$ & Cylinder pressure transducer (bar) \\
\hline $\mathbf{F}$ & Calorimeter water flow & $\mathbf{T 4}$ & Calorimeter water outlet temperature & $\mathbf{N}$ & RPM Decoder \\
\hline
\end{tabular}

Software:-The software particularly designed by Apex Innovation Pvt. Ltd. Sangli, for the Engineering and Research students to demonstrate working of Internal Combustion Engine and study the effect of several parameter in the combustion and performance in the engine. Software is fully configurable.

\section{Results and Discussion}

Variation in combustion characteristics, performance characteristics \& emissions characteristics are discussed in subsequent paragraphs.

\section{Combustion Characteristics}

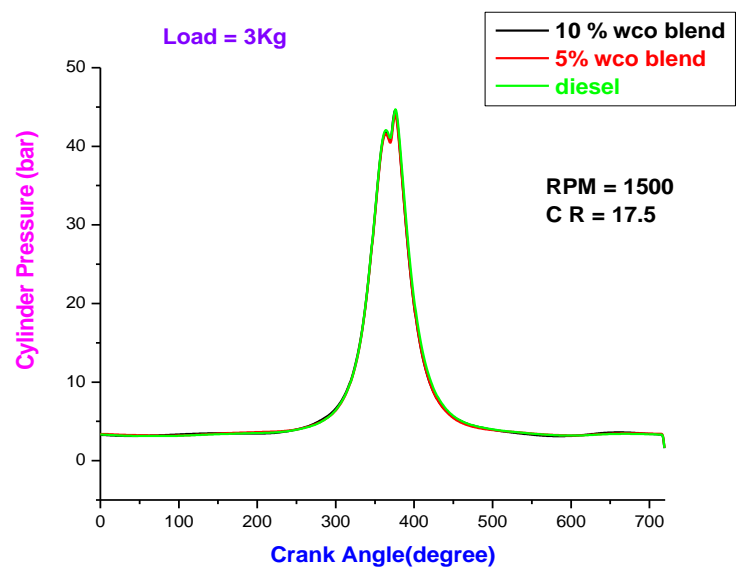

Fig 5.1 Cylinder pressure Vs Crank Angle (3Kg)

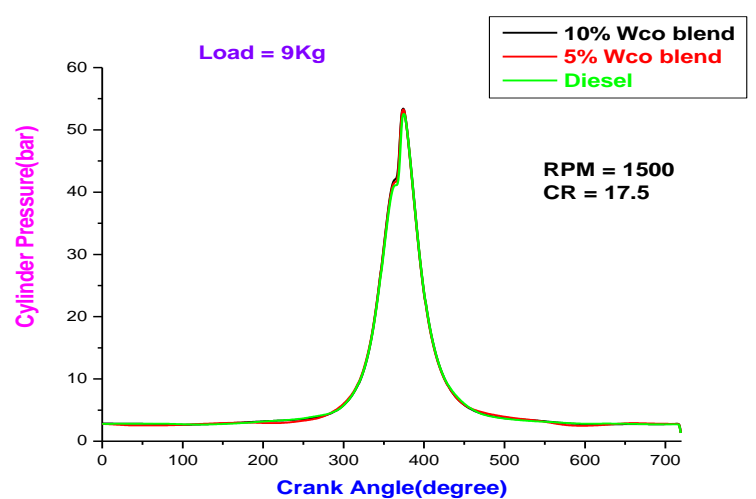

Fig 5.2 Cylinder pressure Vs Crank Angle (9kg)

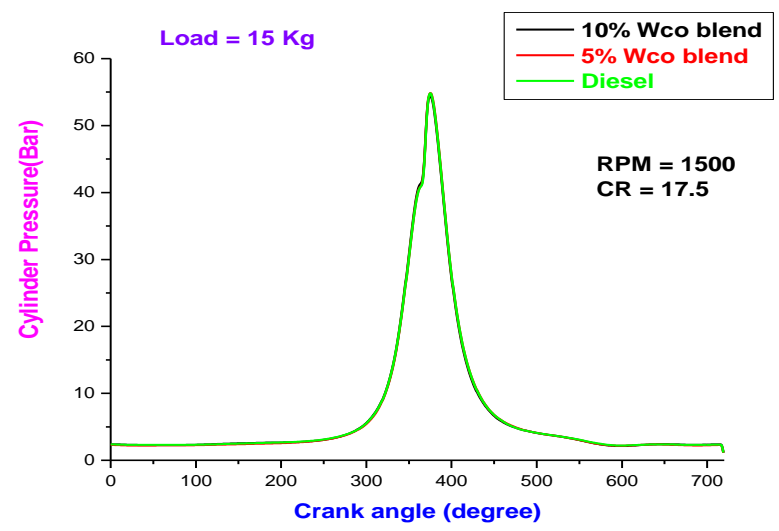

Fig 5.3 Cylinder pressure Vs Crank Angle (15Kg) 
Cylinder pressure with respect to crank angle is essential for the combustion analyses and monitoring the engine behavior. The piezo sensor employed in the effectively generate the At lower load the peak pressure at $10 \%$ WCO is higher than 5\% WCO. Al through the cetane number at $10 \%$ waste cooking oil is higher than 5\% WCO which should permit lower delay period for $10 \%$ WCO but the increased viscosity of $10 \%$ WCO results in poor atomization and poor mixing with air which result higher delay period, thus resulted in higher peak pressure. At higher load the gas temperature increases which reduce the viscosity of the fuel. Thus better atomization achieved. Thus the higher cylinder pressure is observed of higher load. The variation of cylinder pressure with crank angle for diesel and WCO blends with diesel on different loads shown below in table -5.1 , table -5.2 and table -5.3 combustion parameter. The variation of cylinder pressure with crank angle for WCO blends and its different loads can be seen in fig-5.1, fig- 5.2 and fig5.3.

Table 5.1 Maximum Cylinder Pressure Diesel

\begin{tabular}{|c|c|c|c|c|c|c|c|c|}
\hline \multirow{2}{*}{ Parameter } & Fuel & \multicolumn{9}{c|}{ Diesel } \\
\cline { 2 - 11 } & Load & $\mathbf{3}$ & $\mathbf{5}$ & $\mathbf{7}$ & $\mathbf{9}$ & $\mathbf{1 1}$ & $\mathbf{1 3}$ & $\mathbf{1 5}$ \\
\hline \multicolumn{2}{|c|}{ Max.C.P. (Bar) } & 44.71 & 46.35 & 50.56 & 53.45 & 54.13 & 54.20 & 54.86 \\
\hline \multicolumn{2}{|c|}{ Crank angle (Deg.) } & 376 & 376 & 375 & 374 & 374 & 374 & 375 \\
\hline
\end{tabular}

Table 5.2 Maximum Cylinder Pressure 5\% WCO Blends

\begin{tabular}{|c|c|c|c|c|c|c|c|c|}
\hline \multirow{2}{*}{ Parameter } & Fuel & \multicolumn{7}{|c|}{$\mathbf{5 \%}$ Waste cooking oil blend } \\
\cline { 2 - 11 } & Load & $\mathbf{3}$ & $\mathbf{5}$ & $\mathbf{7}$ & $\mathbf{9}$ & $\mathbf{1 1}$ & $\mathbf{1 3}$ & $\mathbf{1 5}$ \\
\hline Max.C.P. (Bar) & 44.01 & 48.41 & 50.34 & 53.28 & 54.27 & 54.37 & 54.88 \\
\hline \multicolumn{2}{|c|}{ Crank angle (Deg.) } & 376 & 375 & 375 & 374 & 374 & 374 & 375 \\
\hline
\end{tabular}

Table 5.3 Maximum Cylinder Pressure 10\% WCO Blends

\begin{tabular}{|c|c|c|c|c|c|c|c|c|}
\hline \multirow{2}{*}{ Parameter } & Fuel & \multicolumn{9}{|c|}{$\mathbf{1 0 \%}$ Waste cooking oil blend } \\
\cline { 2 - 11 } & Load & $\mathbf{3}$ & $\mathbf{5}$ & $\mathbf{7}$ & $\mathbf{9}$ & $\mathbf{1 1}$ & $\mathbf{1 3}$ & $\mathbf{1 5}$ \\
\hline \multicolumn{2}{|c|}{ Max.C.P. (Bar) } & 44.54 & 48.34 & 50.93 & 53.43 & 54.53 & 54.40 & 54.44 \\
\hline \multicolumn{2}{|c|}{ Crank angle (Deg.) } & 376 & 375 & 374 & 374 & 374 & 374 & 375 \\
\hline
\end{tabular}

The variation of rate of pressure rise with crank angle for diesel and WCO blends with diesel and its different loads below in table -5.4 , table -5.5 and table -5.6 .

Table 5.4 Maximum Rate of Pressure Rise Diesel

\begin{tabular}{|c|c|c|c|c|c|c|c|c|}
\hline \multirow{2}{*}{ Parameter } & Fuel & \multicolumn{7}{|c|}{ Diesel } \\
\cline { 2 - 10 } & Load & $\mathbf{3}$ & $\mathbf{5}$ & $\mathbf{7}$ & $\mathbf{9}$ & $\mathbf{1 1}$ & $\mathbf{1 3}$ & $\mathbf{1 5}$ \\
\hline \multicolumn{2}{|c|}{ Max.R.P.R.(Bar/Deg) } & 1.10 & 1.36 & 2.14 & 2.41 & 2.64 & 2.52 & 2.54 \\
\hline \multicolumn{2}{|c|}{ Crank angle (Deg.) } & 350 & 370 & 369 & 369 & 368 & 368 & 367 \\
\hline
\end{tabular}

Table 5.5 Maximum Rate of Pressure Rise 5\% WCO Blends

\begin{tabular}{|c|c|c|c|c|c|c|c|c|}
\hline \multirow{2}{*}{ Parameter } & Fuel & \multicolumn{9}{|c|}{$\mathbf{1 0 \%}$ Waste cooking oil blend } & $\mathbf{1 1}$ & $\mathbf{1 3}$ & $\mathbf{1 5}$ \\
\cline { 2 - 10 } & Load & $\mathbf{3}$ & $\mathbf{5}$ & $\mathbf{7}$ & $\mathbf{9}$ & $\mathbf{1 1}$ & 2.38 \\
\hline \multicolumn{2}{|c|}{ Max.R.P.R.(Bar/deg) } & 1.10 & 1.54 & 2 & 2.41 & 2.51 & 2.37 & 367 \\
\hline \multicolumn{2}{|c|}{ Crank angle (Deg.) } & 348 & 369 & 369 & 368 & 368 & 367 & 367 \\
\hline
\end{tabular}

\section{Performance Characteristics}

Engine performance characteristics are a convenient graphical presentation of an engine performance. They are constructed from the data obtained during actual test run on engine with different WCO blends. In this section some of the important performance characteristics of the CI engine are discussed.

\section{Mechanical Efficiency Vs Torque}

It is observed that for lower and normal value of torque mechanical efficiency is higher for $10 \%$ WCO compared to diesel and 5\% WCO. This is due to the fact the friction power reduce for $10 \%$ WCO as it has higher value of viscosity. The 5\% WCO has mechanical efficiency lower than 10\% WCO. Diesel is observed to have lowest mechanical efficiency

\section{Brake Power Vs Load}

The brake power generated by the engine under dissimilar load at constant speed 1500 r.p.m. is illustrated in fig - 5.5. It can be observed that the load increases the brake power produced by the engine also increases for all blends of fuel. 


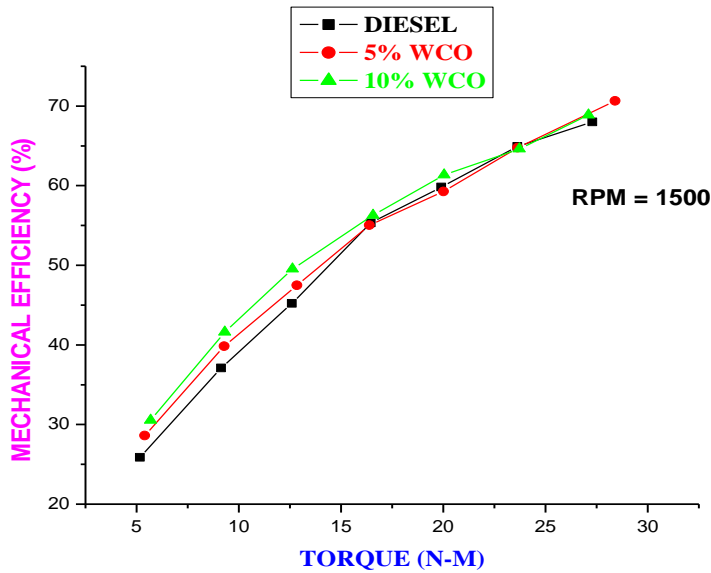

Fig 5.4 Mechanical Efficiency Vs Torque

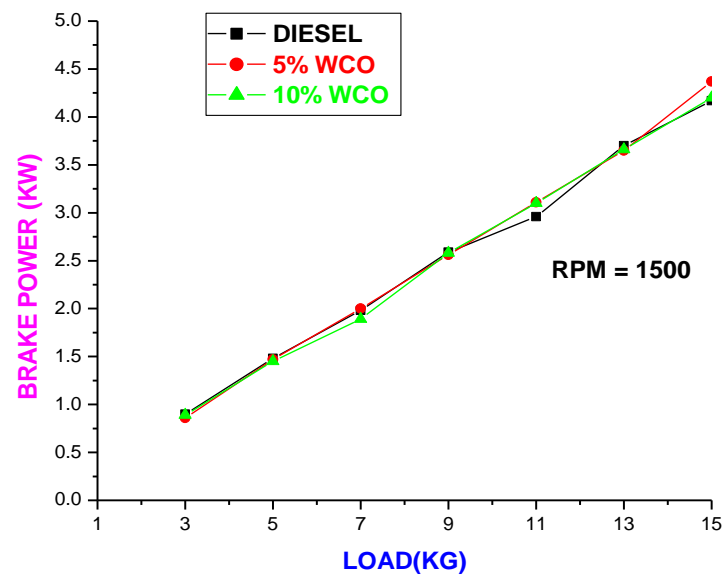

Fig 5.5 Brake Power Vs Load

\section{Brake Power Vs Specific Fuel Consumption}

The specific fuel consumption of various WCO blends and conventional diesel is shown in fig - 5.6. It is observed that SFC is higher for all WCO blends than diesel under various loading condition. SFC is $0.25 \mathrm{Kg} /$ KWh for WCO $10 \%$ blends and $0.23 \mathrm{Kg} / \mathrm{KWh}$ for conventional diesel fuel. This is due to high viscosity, density and lower heating value of WCO blends.

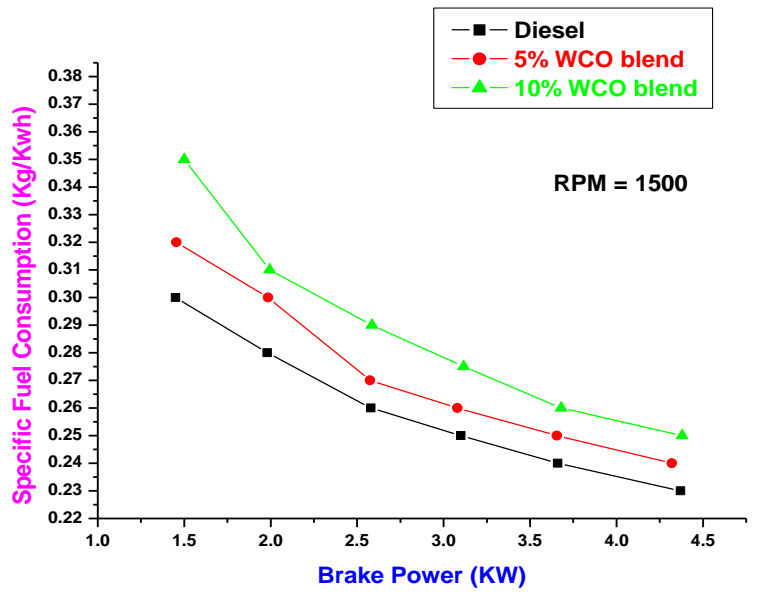

Fig 5.6 Brake Power Vs Specific Fuel Consumption
Brake Thermal Efficiency Vs Brake Mean Effective Pressure

The variations of brake thermal efficiency with brake mean effective pressure for waste cooking oil blends and diesel can be seen in fig - 5.7. Brake thermal efficiency increases with increase in brake mean effective pressure (engine output). Blends of WCO resulted in lower brake thermal efficiency as compared to diesel. The highest brake thermal efficiency $41.12 \%$ was at 5.18 bar BMEP for diesel where as it $35.79 \%$ at 5.2 bar for $5 \%$ WCO blend and $33.90 \%$ at 5.25 bar for $10 \%$ WCO blend. Lower brake thermal efficiency of WCO blends is due to its poor combustion as a result of higher density and viscosity.

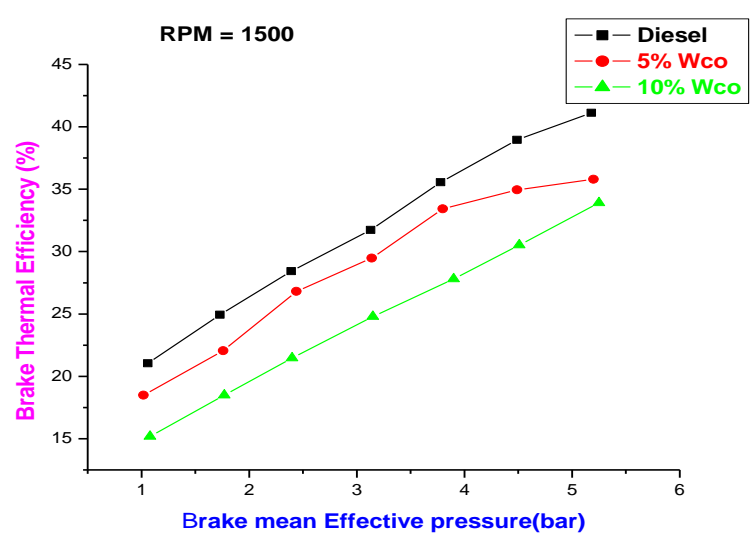

Fig 5.7 Brake Thermal Efficiency Vs Brake Mean Effective Pressure

\section{Emissions Characteristics}

Engine emission has presented over a convenient graphical method. These graphs are based on data collected from the AVL DIGAS 444 gas analyzer at different loads where analyzer produces gases and incomplete combustion substances. In this research paper some of the important emission from CI engine are discussed.

\section{Load Vs Carbon Dioxide}

The change of loads with the $\mathrm{CO}_{2}$ for WCO blends with diesel is shown and discussed below. The $\mathrm{CO}_{2}$ emissions for all the blends at every single load is high when compare with the pure diesel. WE found less $\mathrm{CO}_{2}$ emissions for conventional diesel with B10 blend. The B5 blend shows approximately equal $\mathrm{CO}_{2}$ emissions with diesel. These results may be due to incomplete combustions at higher load because the emission of $\mathrm{CO}_{2}$ results from the incomplete combustions of hydro carbon. 


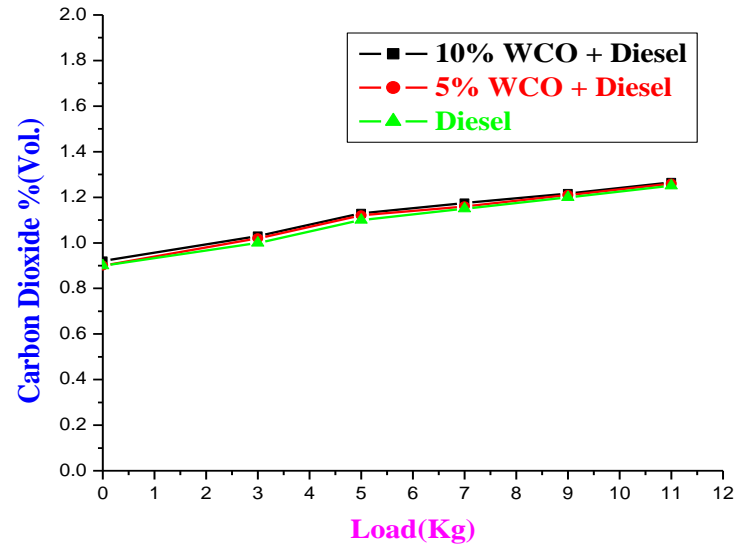

Fig 5.8 Load Vs carbon Dioxide

\section{Load Vs carbon Monoxide}

The comparison of CO emissions of WCO blends with diesel shown in fig-5.9. $\mathrm{CO}$ is the intermediate compound during intermediate combustion of combustion of HC fuels. Carbon mono oxide formation depend over air-fuel equivalence ratio, type of fuel, design of combustion chamber, fuel injection timing, injection pressure and velocity. Experiment results shows that the concentration of $\mathrm{CO}$ in WCO blends is less when compare with diesel. When the load is increases the value of $\mathrm{CO}$ decreases due to higher viscosity of WCO which increases the size of droplet and improved the atomization.

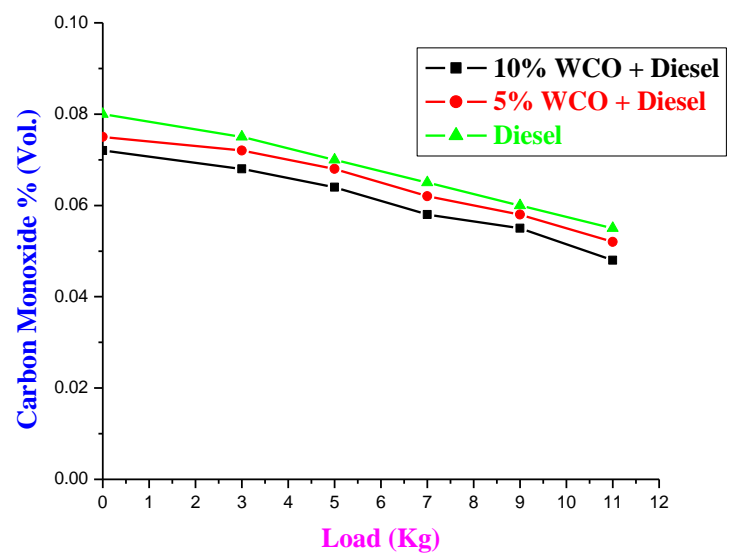

Fig 5.9 Load Vs carbon Monoxide

\section{Load Vs Hydro Carbon}

The variation of hydro carbon at different loads for different blends are shown below in fig. it can be evaluated from the graph that HC emissions are high for all the blends at all the loads as compared to diesel. The HC decreases with increases in loads. It is seenl) that the $\mathrm{HC}$ of the engine for conventional diesel is less compare to WCO blends, This happens may be due to the poor atomization of the waste cooking oil blends, because of higher viscosity, high density with poor volatiliy.

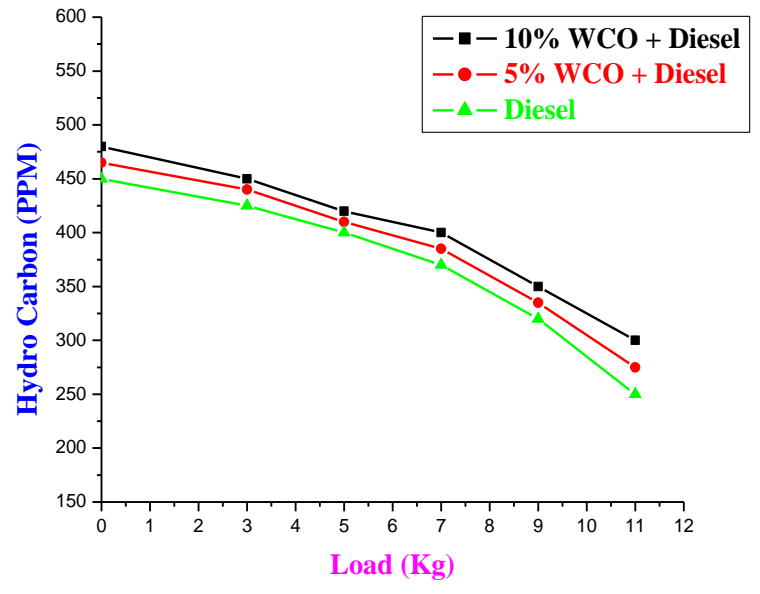

Fig 5.10 Load Vs Hydro Carbon

\section{Load Vs Nitric Oxide}

The variation of $\mathrm{NO}_{\mathrm{x}}$ with load for WCO blends and diesel shown in the graph fig. 5.11 We found that $\mathrm{NO}_{\mathrm{X}}$ emissions for all the blends at each load is high as compare to the diesel. when the load is increases the $\mathrm{NO}_{\mathrm{x}}$ emission also increases. In the graph we can see that the $\mathrm{NO}_{\mathrm{x}}$ for diesel is higher than the B10 blend. This may happen due to the higher temperature during the combustion in the cylinder when load increases.

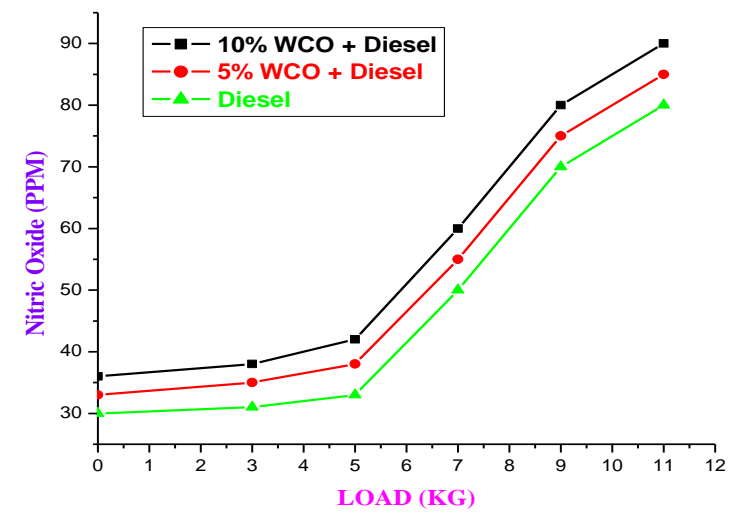

Fig 5.11 Load Vs Nitric Oxide

\section{Conclusion}

The following points are concluded from the work of combustion, performance and emission analyses of B5 and B10 with the conventional diesel for compression ratio(r) 17.5:1. Increasing the percentage value of WCO reduces the Calorific value(CV) or Heating value when compare with the diesel. CI engine can run with blends with out any changes in engine setup.

2) It is not only for reducing the cost by WCO blending but also for preserve the millions of liters of diesel for future.

3) The CI engine can run satisfactorily with WCO blend with Diesel fuel with out modification. 
4) There are essential properties of diesel and WCO blends which are similar and both are easy to mix without using any external agent.

5) The expected Brake power reduces due to the lower calorific value or heating value of WCO.

6) Specific fuel consumption of WCO blends is higher than the conventional diesel due to its lower calorific value.

7) WCO and its blends with diesel have high viscosity than the conventional diesel. The high viscosity of WCO blends affected the atomization property, may be affected the combustion efficiency. but on other hand WCO and its blends treat as a lubricator too which improves the Mechanical Efficiency.

8) The CO emissions is higher for WCO and its blend then diesel.

9) Lower calorific value, viscosity and lower calorific value of WCO reduces combustion quality.

10) The high value of cetane number reduces the production of UBHC during injection of fuel before the starting of combustion.

11) The HC and NOx emission is higher for WCO blends and for diesel and it may be due to the poor atomization and improper combustion.

Hence we can conclude that Waist cooking oil blend with diesel is help in controlling the air pollution. Hence by encouraging the WCO collection centers and running the awareness programs in human life. we can save the diesel fuel as well as also ensure the harmful effects due to reuse of cooking oil.

\section{References}

S. Ram Kumar, V. Kirubakaran (2016), Biodiesel from vegetable oil as alternate fuel for C.I engine and feasibility study of thermal cracking, Science direct energy conversion management ,118,pp 155-169.
K. Nantha Gopal, Arindam Pal, Sumit Sharma, Charan Samanchi, K. Sathyanarayanan, T. Elango (2014). Investigation of emissions and combustion characteristics of a CI engine fueled with waste cooking oil methyl ester and diesel blends, Science direct Alexandria engineering journal , 53,pp 281-287.

S. Kathirvel, Apurba Layek, S. Muthuraman (2016), Exploration of waste cooking oil methyl esters (WCOME) as fuel in compression ignition engines, A review science direct engineering science and technology an international journal ,19, pp 1018- 1026.

K. Muralidharan, D. Vasudevan (2011), Performance, emission and combustion characteristics of a variable compression ratio engine using methyl esters of waste cooking oil and diesel blends, Science direct applied energy, 88, pp 3959-3968.

A. Abu-Jrai, Jehad A. Yamin, Ala'a H, Al-Muhtaseb, Muhanned A. Hararah(2011), Combustion characteristics and engine emissions of a diesel engine fueled with diesel and treated waste cooking oil blends, Science direct chemical engineering journal ,172,pp 129-136.

X.J. Man, C.S. Cheung, Z. Ning, L. Wei, Z.H. Huang(2016), Influence of engine load and speed on regulated and unregulated emissions of a diesel engine fueled with diesel fuel blended with waste cooking oil biodiesel, Science direct fuel journal,180, pp 41-49.

H. An, W.M. Yang, A. Maghbouli, J. Li, S.K. Chou, K.J. Chua(2013), Performance, combustion and emission characteristics of biodiesel derived from waste cooking oils, Science direct applied energy journal,112 ,pp 493- 499.

M. Senthil Kumar, M. Jaikumar(2014) ,A comprehensive study on performance, emission and combustion behavior of a compression ignition engine fuelled with WCO (waste cooking oil) emulsion as fuel, Science direct journal of energy, 87, [2014] 263-271. 